\title{
The Recovery of Phosphorus from Acidic Ultra-High Phosphorous Wastewater by the Struvite Crystallization
}

\author{
Qiang $\mathrm{Li}^{1,+}$, Song Wang ${ }^{2,3,+}$, Lifang Wang ${ }^{1}$, Li Zhang ${ }^{3, *}$, Xiaohui Wan ${ }^{3}$ and Zhiguo Sun ${ }^{3, *}$ \\ 1 School of Management, Northwestern Polytechnical University, 127 West Youxi Road, Xian 710072, China; \\ failureend@163.com (Q.L.); lifang@nwpu.edu.cn (L.W.) \\ 2 Shangtex Architectural Design Research Institute Co., Ltd., Shanghai 200060, China; 13122337565@163.com \\ 3 Research Center of Resource Recycling Science and Engineering, School of Environmental and Materials \\ Engineering, Shanghai Polytechnic University, Shanghai 201209, China; wxhwanxiaohui@163.com \\ * Correspondence: zhangli@sspu.edu.cn (L.Z.); zgsun@sspu.edu.cn (Z.S.); \\ Tel.: +86-15021711269 or +86-021-50211210 (L.Z.) \\ + These authors contribute equally to this work.
}

Received: 4 February 2020; Accepted: 18 March 2020; Published: 26 March 2020

\begin{abstract}
Phosphorus recovery from industrial wastewater has attracted considerable interest. In this study, struvite crystallization method has been used for treatment of high phosphorus wastewater. The new combination agents of $\mathrm{Mg}_{5}\left(\mathrm{CO}_{3}\right)_{4}(\mathrm{OH})_{2} \cdot 4 \mathrm{H}_{2} \mathrm{O}$ and $\mathrm{NH}_{4} \mathrm{Cl}$ were used as the precipitant. The effects of initial $\mathrm{pH}, \mathrm{n}(\mathrm{Mg}): \mathrm{n}(\mathrm{P}), \mathrm{n}(\mathrm{N}): \mathrm{n}(\mathrm{P})$, and reaction time on the removal of total phosphorus (TP) in wastewater were investigated. The results showed that under the condition of initial $\mathrm{pH}=4$, $\mathrm{Mg}: \mathrm{N}: \mathrm{P}=1.2: 1.1: 1$, reaction time for $30 \mathrm{~min}$, and static storage for $20 \mathrm{~min}$, the residual amount of TP in wastewater was $2.98 \mathrm{mg} / \mathrm{L}$, and the removal rate of TP reached $99.99 \%$. The mass fraction of $\mathrm{P}_{2} \mathrm{O}_{5}$ in the generated sediment reached $25.22 \%$, equivalent to high grade phosphate ore and slow-release fertilizer, so as to realize the recycling and utilization of phosphorus in ultra-high phosphorous wastewater. This work will have practical application potential in treatment of high phosphorus wastewater and environmental management.
\end{abstract}

Keywords: struvite crystallization method; environmental management; ultra-high phosphorus wastewater; basic magnesium carbonate; phosphorus recovery

\section{Introduction}

Nowadays, with the increasing demand for aluminum and its alloys in the world, the surface treatment processes, such as phosphating, are often used to protect the surface of materials from oxidation and corrosion [1,2]. The phosphating process contains a series of chemical reactions, and thus lots of acidic ultra-high phosphorous wastewater was produced [3]. The composition of phosphating wastewater produced in the processing of aluminum profiles is complex, and direct discharge will seriously pollute the surrounding ecological environment [4]. When the total phosphorus (TP) concentration in the water body is higher than $0.02 \mathrm{mg} / \mathrm{L}$, it is considered as eutrophic water, which would cause strong algae metabolism, consume a large amount of dissolved oxygen, cause a large number of aquatic organisms to die, and release a large amount of toxic gases: $\mathrm{H}_{2} \mathrm{~S}, \mathrm{NH}_{3}, \mathrm{CH}_{4}$, etc., leading to deterioration of water quality, disrupting the ecological balance and stability of water bodies, and increasing the difficulty and cost of water treatment [5]. So, the removal of phosphorus from wastewater is of great significance for environmental protection.

Current methods for phosphorus removal include biological method, physical adsorption method, electrodialysis method, ion exchange method, chemical precipitation method, etc., [6]. The biological 
method is susceptible to factors such as wastewater chemical composition, process parameters, and structure size [7]. Therefore, the process of biological method is unstable, and the phosphorus removal in the form of sludge will eventually cause secondary pollution [8]. The physical adsorption has a disadvantage of low adsorption efficiency of the adsorbent [9]. The electrodialysis process has high requirements on the ion selectivity of the permeation membrane itself, and is only suitable for enterprises with a small amount of wastewater with a single component [10]. Ion exchange method also has high selectivity for exchange objects, and can only handle solutions with lower ion concentrations [11]. The reproducibility of ion exchange resins is also a major problem. The chemical precipitation treatment of phosphorus is to separate the phosphorus by the precipitation reaction between orthophosphate and metal ions. Common metal salts that can react with soluble phosphate to form insoluble matter include calcium, aluminum, ammonium, magnesium salts, and iron [12]. The chemical precipitation method has a high removal rate and is widely used in the treatment of industrial high-concentration phosphorus-containing wastewater, but this method can only "remove phosphorus," not "recycle phosphorus" [13]. Phosphorus is a precious natural resource on the earth, and it is also one of the indispensable elements that make up living matter. The large-scale exploitation of phosphate rock and the neglect of phosphorus resource recovery have led to the depletion of phosphorus resources [14]. Because of the non-renewable nature of phosphorus resources, the sustainable use of phosphorus resources has received increasing attention in recent years [15]. Research on recovering phosphorus using struvite $\left(\mathrm{MgNH}_{4} \mathrm{PO}_{4} \cdot 6 \mathrm{H}_{2} \mathrm{O}\right.$, referred to as MAP) crystallization has also received widespread attention from scientists [16]. Struvite crystallization means that when the concentrations of $\mathrm{Mg}^{2+}$, $\mathrm{PO}_{4}{ }^{3-}$, and $\mathrm{NH}_{4}{ }^{+}$in wastewater reaches the solubility product $\left(\mathrm{K}_{\mathrm{sp}}\right)$ of struvite, $\mathrm{NH}_{4}{ }^{+}$and $\mathrm{PO}_{4}{ }^{3-}$ are precipitated and removed as struvite crystals, as shown in formula (1).

$$
\mathrm{Mg}^{2+}+\mathrm{NH}_{4}{ }^{+}+\mathrm{H}_{\mathrm{n}} \mathrm{PO}_{4}{ }^{3-\mathrm{n}}+6 \mathrm{H}_{2} \mathrm{O} \rightarrow \mathrm{MgNH}_{4} \mathrm{PO}_{4} \cdot 6 \mathrm{H}_{2} \mathrm{O} \downarrow+\mathrm{nH}^{+}
$$

This method can not only efficiently remove high-concentration ammonia nitrogen and water-soluble phosphorus in wastewater, but also produce struvite as a slow-release fertilizer for agricultural production and flower cultivation [17]. Struvite crystallization has been extensively studied for removal of nitrogen and phosphorus in wastewater [17,18]. However, for high-concentration acidic phosphorus-containing wastewater (total phosphorus content of $\sim 24,500 \mathrm{mg} / \mathrm{L}$ ) generated in the processing of aluminum profiles, reducing the phosphorus content to the discharge standard $(\leq 5 \mathrm{mg} / \mathrm{L})$ remains a challenge. Thus, the main aim of this work is studying the factors affecting the recovery of phosphorus in acidic ultrahigh-phosphorus wastewater by struvite crystallization, such as the proportion of reactant materials, initial $\mathrm{pH}$, and reaction time. The study found that using basic magnesium carbonate as the source of magnesium for struvite precipitation can take advantage of the alkaline nature of the basic magnesium carbonate aqueous solution, raise the $\mathrm{pH}$ of wastewater, and reduce the use of alkali. It can also ensure that the TP content in the treated wastewater meets the standard discharge and recover higher purity phosphorus resources, which has a high potential economic value.

\section{Materials and Methods}

\subsection{Materials}

Calcium oxide was purchased from Tianjin Bodi Chemical Co., Ltd., and magnesium chloride was purchased from Kunming Huangbao Trading Company. Ammonium chloride, calcium chloride, sulfuric acid, magnesium hydroxide, potassium antimony tartrate, nitric acid, and perchloric acid were purchased from Sinopharm Chemical Reagent Co., Ltd. (Shanghai, China). Ammonium molybdate was purchased from Tianjin Chemical Reagent Kaida Plant, and ascorbic acid was purchased from Tianjin Dingshengxin Chemical Co., Ltd.; sodium hydroxide was purchased from Shanghai Titan Technology Co., Ltd. Ammonium bicarbonate was purchased from Shanghai Aladdin Biochemical Technology Co., Ltd. The filter paper $(\Phi 15$, medium speed) was purchased from Wendong Chemical 
Co., Ltd. (Shanghai, China), and the needle filter $(0.22 \mu \mathrm{m})$ was purchased from ALWSCI (Hangzhou, China). All reagents were of analytical purity and not further processed before use.

\subsection{Methods}

The wastewater in the experiment is provided by Haiyan County Saixin Metal Surface Treatment Co., Ltd. (Haiyan, China), with the main pollutants in wastewater is shown in Table 1. It was determined that the proportion of phosphorus in soluble orthophosphate to TP was $98.52 \%$. In order to eliminate the influence of sulfate ion in the waste liquid and recover the high-purity phosphorus resources, the waste liquid needs to be pre-treated as follows: an appropriate amount of the above-mentioned wastewater was taken, and calcium oxide was added thereto at a concentration of $38 \mathrm{~g} / \mathrm{L}$ to remove sulfate. The filter was used to filter out the precipitate. After analysis, it was found that the amount of dry mud produced in this step was about $73 \mathrm{~g} / \mathrm{L}$, and the main component was calcium sulfate. The removal rate of sulfate in the waste liquid reached $90 \%$, while the concentration of phosphate was basically unchanged, and the $\mathrm{pH}$ of the solution increased from 0.6 to 1.8 . Continuously adding sodium hydroxide to the filtered waste liquid to a $\mathrm{pH}$ of 4.0, a precipitate is formed due to the presence of small amount aluminum ions in the wastewater. The supernatant was filtered and the magnesium salt and ammonium salt were added according to the set molar ratio. Struvite precipitated in the waste liquid after stirring for 30 minutes, and then it was allowed to stand for 20 minutes. After that, the supernatant was filtered and the TP content was measured.

Table 1. The parameters of the wastewater sample.

\begin{tabular}{ccc}
\hline Items & Units & Parameters \\
\hline $\mathrm{pH}$ & & 0.6 \\
$\mathrm{TP}$ & $\mathrm{mg} / \mathrm{L}$ & $24,000-25,000$ (avg.: $24,500.00)$ \\
$\mathrm{Al}$ & $\mathrm{mg} / \mathrm{L}$ & 4300.00 \\
$\mathrm{SO}_{4}$ & $\mathrm{mg} / \mathrm{L}$ & $30,000-60,000$ (avg.: 55,000.00) \\
$\mathrm{NO}_{3}$ & $\mathrm{mg} / \mathrm{L}$ & 164.50 \\
$\mathrm{Cl}$ & $\mathrm{mg} / \mathrm{L}$ & 46.30 \\
$\mathrm{Mo}$ & $\mathrm{mg} / \mathrm{L}$ & 42.10 \\
$\mathrm{Ti}$ & $\mathrm{mg} / \mathrm{L}$ & 77.60 \\
$\mathrm{Fe}$ & $\mathrm{mg} / \mathrm{L}$ & 17.70 \\
$\mathrm{As}$ & $\mu \mathrm{L} / \mathrm{L}$ & 56.90 \\
$\mathrm{Sb}$ & $\mu \mathrm{L} / \mathrm{L}$ & \\
\hline
\end{tabular}

\subsection{Analysis}

The precipitate was dried at $75{ }^{\circ} \mathrm{C}$ to constant weight and ground to a powder to analyze the crystal composition and microstructure by X-ray diffraction (XRD, Rigaku-D/max 2550 PC, Japan) and scanning electron microscope (SEM, Hitachi S-4800, Japan). TP is measured using ammonium molybdate spectrophotometry (Chinese National Standard: GB/T 11894-1989). The model of the spectrophotometer is V1800, Unico Instrument Co., Ltd., Shanghai. The concentration of sulfate ion was measured by ion chromatography (ICS-2100, Dion (China) Co., Ltd.). The concentration of metals ions was measured by inductively coupled plasma atomic emission spectroscopy (ICP-AES, A-6300, Thermo Fisher, USA). The ammonia nitrogen content in the wastewater was measured using the Nessler's reagent spectrophotometry (China Environmental Industry Standard: HJ 535-2009), and the model of the spectrophotometer was the same as that used to measure the TP content.

\section{Results and Discussion}

\subsection{Effect of Initial $\mathrm{pH}$}

The original $\mathrm{pH}$ of the experimental wastewater of 0.6 is not suitable for struvite precipitation [19]. If the $\mathrm{pH}$ is directly adjusted to be alkaline, the amount of alkaline solution consumed is too large 
and the cost is too high. The group of reagents of $\mathrm{Mg}_{5}\left(\mathrm{CO}_{3}\right)_{4}(\mathrm{OH})_{2} \cdot 4 \mathrm{H}_{2} \mathrm{O}$ and $\mathrm{NH}_{4} \mathrm{Cl}$ was selected in consideration of the fact that $\mathrm{Mg}_{5}\left(\mathrm{CO}_{3}\right)_{4}(\mathrm{OH})_{2} \cdot 4 \mathrm{H}_{2} \mathrm{O}$ can be dissolved in dilute acid and neutralize the acid in solution to a greater extent than the ammonium radical hydrolysis to produce hydrogen. So adjust the $\mathrm{pH}$ of the original wastewater to 4.0,5.0, and 6.0, and take the filtrate after filtration. According to the concentration of TP in the filtrate, add $\mathrm{Mg}_{5}\left(\mathrm{CO}_{3}\right)_{4}(\mathrm{OH})_{2} \cdot 4 \mathrm{H}_{2} \mathrm{O}$ and $\mathrm{NH}_{4} \mathrm{Cl}$ according to the theoretical Mg:N:P molar ratio of 1:1:1. The reaction was stirred for 30 minutes, left to stand for 20 minutes, filtered, the TP content and $\mathrm{pH}$ in the filtrate were measured, and the TP removal rate was calculated. The experimental data are shown in Table 2.

Table 2. Concentration of total phosphorus (TP) after reaction at different initial $\mathrm{pH}$.

\begin{tabular}{cccc}
\hline Initial $\mathbf{~ p H}$ & Mg:N:P & TP $(\mathbf{m g} / \mathbf{L})$ & $\mathbf{p H}$ After Reaction \\
\hline 4.0 & $1: 1: 1$ & 5.86 & 7.30 \\
5.0 & $1: 1: 1$ & 6.10 & 7.80 \\
6.0 & $1: 1: 1$ & 5.68 & 8.10 \\
\hline
\end{tabular}

As shown in Table 2, $\mathrm{Mg}_{5}\left(\mathrm{CO}_{3}\right)_{4}(\mathrm{OH})_{2} \cdot 4 \mathrm{H}_{2} \mathrm{O}$ and $\mathrm{NH}_{4} \mathrm{Cl}$ were added with $\mathrm{Mg}: \mathrm{N}: \mathrm{P}$ at a molar ratio of 1:1:1. Under different $\mathrm{pH}$ conditions, all the TP concentrations were reduced to less than $10 \mathrm{mg} / \mathrm{L}$, and the TP removal rate all reached $99.98 \%$. The $\mathrm{pH}$ value of the solution after the reaction is in the range of 7.3-8.2, which belongs to the suitable $\mathrm{pH}$ range for struvite crystals. From the data in the table above, it can be seen that the initial $\mathrm{pH}$ is suitable between 4 and 6 , but it is also necessary to determine the optimal working conditions in combination with the material addition ratio.

\subsection{Effects of $M g / P$ and N/P Molar Ratios on TP Removal}

Under the condition of $\mathrm{N}: \mathrm{P}$ as $1: 1$, adjust the $\mathrm{pH}$ to 4.0, 5.0, and 6.0, respectively, add $\mathrm{Mg}_{5}\left(\mathrm{CO}_{3}\right)_{4}(\mathrm{OH})_{2} \cdot 4 \mathrm{H}_{2} \mathrm{O}$ with different $\mathrm{Mg}$ : $\mathrm{P}$ molar ratio, stir the solution for $30 \mathrm{~min}$ and let it stand for $20 \mathrm{~min}$. The effects of $\mathrm{Mg}$ :P with different molar ratios on TP removal is shown in Figure $1 \mathrm{~A}$. The TP removal in wastewater is improved with increasing of $\mathrm{Mg}: \mathrm{P}$ molar ratio. Among them, when the initial $\mathrm{pH}$ is 4.0, the overall TP removal effect is the best. When Mg:P reached 1.1:1, the TP concentration decreased to less than $5 \mathrm{mg} / \mathrm{L}$. When $\mathrm{Mg}: \mathrm{P}$ is higher than 1.3:1, the effect of TP removal is basically unchanged or even reduced.

Fixing Mg:P to 1:1, adjusting different $\mathrm{pH}$ to 4.0, 5.0, and 6.0, and then $\mathrm{NH}_{4} \mathrm{Cl}$ with different $\mathrm{N}: \mathrm{P}$ molar ratio was added into the wastewater. The effect of molar ratios of $\mathrm{N}$ : P on TP removal is shown in Figure 1B. It can be seen that when N:P molar ratio is increased, the TP concentrations in the wastewater also decrease. When the initial $\mathrm{pH}$ is 6.0, the overall removal effect of TP is the best, followed by the phosphorus removal effect with the initial $\mathrm{pH}$ at 4.0. When N:P is 1.2:1, the minimum remaining amount of TP is $3.74 \mathrm{mg} / \mathrm{L}$. When $\mathrm{N}$ : P is higher than 1.2:1, the change of TP concentration is small and tends to be stable. 

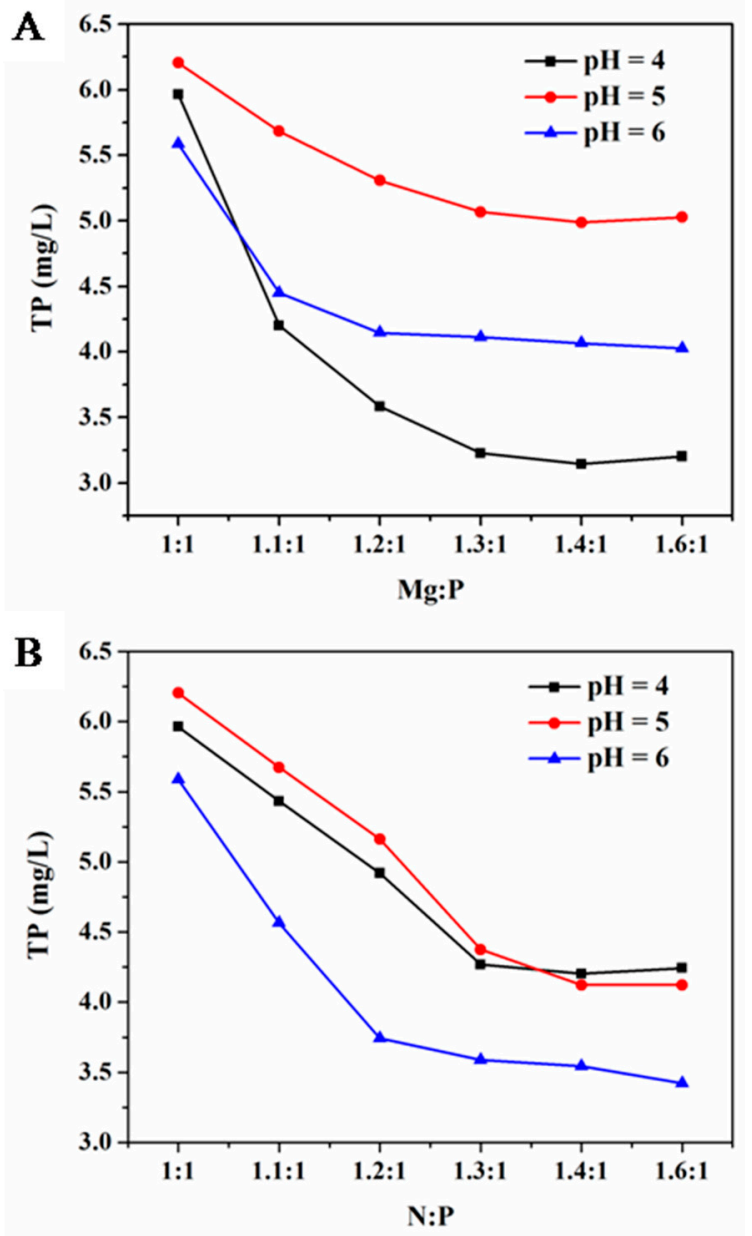

Figure 1. Effect of changing $\mathrm{Mg}: \mathrm{P}(\mathbf{A})$ and $\mathrm{N}: \mathrm{P}(\mathbf{B})$ on TP removal under different $\mathrm{pH}$ conditions.

\subsection{Determination of the Optimal Molar Ratio of $\mathrm{Mg} / \mathrm{N} / \mathrm{P}$}

Increasing Mg:P and N:P separately can promote the removal of phosphorus in wastewater, so a set of cross-contrast experiments are designed, as shown in Table 2. The experimental conditions are: adjusting the $\mathrm{pH}$ to 4.0 , stirring the solution $30 \mathrm{~min}$, and letting it to stand for $20 \mathrm{~min}$. The experimental design and results are shown in Table 3.

Table 3. Combination experiment of different $\mathrm{Mg}: \mathrm{N}: \mathrm{P}$.

\begin{tabular}{ccccc}
\hline Mg:N:P & TP $(\mathbf{m g} / \mathbf{L})$ & TP Removal Rate & $\mathbf{p H}$ After Reaction & Sludge Yield $(\mathbf{g} / \mathbf{L})$ \\
\hline 1.1:1.1:1 & 3.94 & $99.98 \%$ & 7.7 & 43.33 \\
1.15:1.1:1 & 3.70 & $99.98 \%$ & 7.8 & 43.95 \\
$1.2: 1.1: 1$ & 2.98 & $99.99 \%$ & 7.8 & 44.70 \\
\hline $1.1: 1.15: 1$ & 3.66 & $99.99 \%$ & 7.7 & 43.24 \\
$1.15: 1.15: 1$ & 2.94 & $99.99 \%$ & 7.7 & 45.90 \\
$1.2: 1.15: 1$ & 2.86 & $99.99 \%$ & 7.7 & 48.86 \\
\hline $1.1: 1.2: 1$ & 3.30 & $99.99 \%$ & 7.6 & 43.28 \\
$1.15: 1.2: 1$ & 2.86 & $99.99 \%$ & 7.7 & 46.49 \\
$1.2: 1.2: 1$ & 2.78 & $99.99 \%$ & 7.7 & 46.86 \\
\hline
\end{tabular}

As shown in Table 3, it can be seen that the combined experimental results are better than the individual experimental results. The remaining amount of TP is stable below $5 \mathrm{mg} / \mathrm{L}$, and the $\mathrm{pH}$ of the solution after the reaction changes in a small range between 7.6 and 7.9. The sludge yields listed in 
Table 3 refer to the mass of the sediment produced in the single process of struvite precipitation after drying. Considering that the increase of $\mathrm{NH}_{4} \mathrm{Cl}$ dosage will lead to the increase of ammonia nitrogen concentration in the sample, so $\mathrm{Mg}: \mathrm{N}: \mathrm{P}=1.2: 1.1: 1$ is selected as the best dosage ratio, while the TP concentration was $2.98 \mathrm{mg} / \mathrm{L}$.

\subsection{Effect of Reaction Time on TP Removal}

Adjust the $\mathrm{pH}=4.0$, control the material dosing ratio of $\mathrm{Mg}: \mathrm{N}: \mathrm{P}=1.2: 1.1: 1$, and leave it for 20 min to observe the effect of TP removal under different stirring reaction times. As can be seen from Figure 2, when the reaction time was 10 minutes, the TP concentration was $3.30 \mathrm{mg} / \mathrm{L}$, and it remained almost unchanged when the reaction time reached 20 minutes. It can be seen that the formation rate of struvite crystals is very fast, as observed during the experiment that a large amount of precipitation will occur immediately after the magnesium salt and the ammonium salt are added. Comprehensive consideration, the reaction time of $30 \mathrm{~min}$ was selected as the optimal reaction time. At this time, the TP concentration was reduced to $2.98 \mathrm{mg} / \mathrm{L}$, which meet the discharged sewage standard in China ( $\leq 5 \mathrm{mg} / \mathrm{L}$, Quality Standards for Sewage Discharge into Urban Sewers, GB 31962-2015) and can ensure the full progress of the reaction and reduce energy consumption.

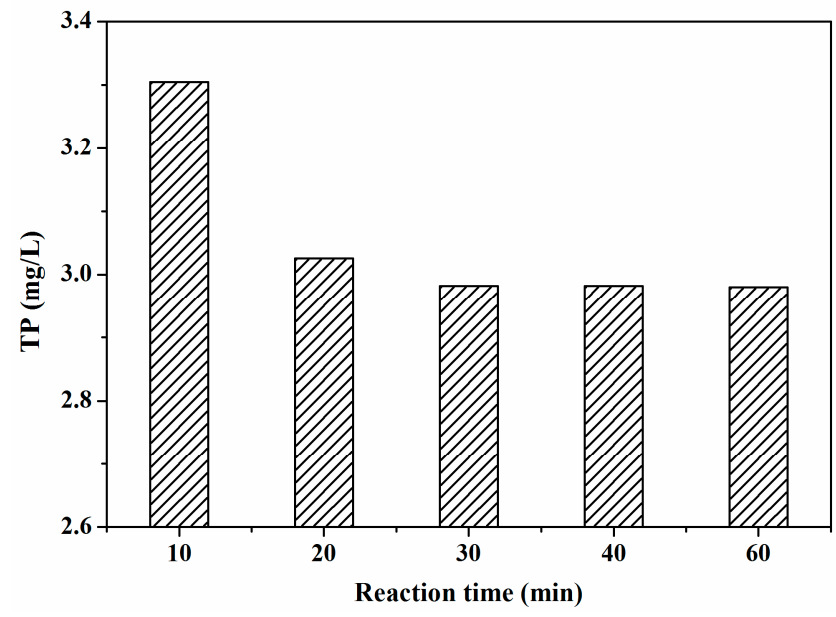

Figure 2. Effect of reaction time on TP removal.

\subsection{Comparison of Struvite Methods Using Different Combinations of Agents}

Comparison of struvite methods using three different combinations of agents are listed in Table 4 . The TP removal rate by the agents groups of $\left[\mathrm{Mg}(\mathrm{OH})_{2}+\mathrm{NH}_{4} \mathrm{Cl}\right],\left[\mathrm{MgCl}_{2} \cdot 6 \mathrm{H}_{2} \mathrm{O}+\mathrm{NH}_{4} \mathrm{HCO}_{4}\right]$, and $\left[\mathrm{Mg}_{5}\left(\mathrm{CO}_{3}\right)_{4}(\mathrm{OH})_{2} \cdot 4 \mathrm{H}_{2} \mathrm{O}+\mathrm{NH}_{4} \mathrm{Cl}\right]$ are $4.91 \mathrm{mg} / \mathrm{L}, 5.72 \mathrm{mg} / \mathrm{L}$, and $2.98 \mathrm{mg} / \mathrm{L}$, separately. In the three groups of reagents, the consumption of magnesium hydroxide was less, because of its lower solubility [20]. Magnesium chloride has low toxicity and excessive intake is harmful to human health, so it is not suitable for large-scale use to reduce phosphorus ions [21,22]. In terms of the pH value of the solution after the reaction, the $\mathrm{pH}$ values of the three groups all meet the discharged sewage standard in China (range of 6.5-9.5, Quality Standards for Sewage Discharge into Urban Sewers, GB 31962-2015). In addition, it can be found that the concentration of sulfate in the wastewater is also reduced. This is because the sulfate and the magnesium salt also react to form a magnesium sulfate precipitate, which can be confirmed from the XRD patterns of struvite precipitation. It can be seen in Figure 3 that the main component of struvite precipitation is magnesium ammonium phosphate, but there is also a small amount of magnesium sulfate [23]. 
Table 4. Comprehensive comparison of ammonium magnesium combined sedimentation agent.

\begin{tabular}{|c|c|c|c|c|}
\hline \multicolumn{2}{|c|}{ Parameters } & $\underset{\mathrm{NH}_{4} \mathrm{Cl}}{\mathrm{Mg}(\mathrm{OH})_{2}}+$ & $\underset{\mathrm{NH}_{4} \mathrm{HCO}_{4}}{\mathrm{MgCl}_{2} \cdot 6 \mathrm{H}_{2} \mathrm{O}+}$ & $\begin{array}{c}\mathrm{Mg}_{5}\left(\mathrm{CO}_{3}\right)_{4}(\mathrm{OH})_{2} \cdot 4 \mathrm{H}_{2} \mathrm{O} \\
+\mathrm{NH}_{4} \mathrm{Cl}\end{array}$ \\
\hline \multirow{7}{*}{$\begin{array}{l}\text { Amount of reagent } \\
\text { used (optimal } \\
\text { molar ratio in } \\
\text { single experiment) }\end{array}$} & $\mathrm{CaO} g / \mathrm{L}$ & 38.00 & 38.00 & 38.00 \\
\hline & $\mathrm{NaOH} \mathrm{mg} / \mathrm{L}$ & 14.60 & 28.10 & 14.60 \\
\hline & $\mathrm{Mg}(\mathrm{OH})_{2} \mathrm{~g} / \mathrm{L}$ & 25.87 & / & / \\
\hline & $\mathrm{NH}_{4} \mathrm{Cl} \mathrm{g} / \mathrm{L}$ & 14.84 & / & 16.30 \\
\hline & $\mathrm{Mg}_{5}\left(\mathrm{CO}_{3}\right)_{4}(\mathrm{OH})_{2} \cdot 4 \mathrm{H}_{2} \mathrm{Og} / \mathrm{L}$ & / & / & 32.20 \\
\hline & $\mathrm{MgCl}_{2} \cdot 6 \mathrm{H}_{2} \mathrm{O} \mathrm{g} / \mathrm{L}$ & / & 50.85 & / \\
\hline & $\mathrm{NH}_{4} \mathrm{HCO}_{4} \mathrm{~g} / \mathrm{L}$ & l & 25.69 & / \\
\hline \multirow{2}{*}{$\begin{array}{l}\text { Content of residual } \\
\text { ions }\end{array}$} & $\mathrm{TP} \mathrm{mg} / \mathrm{L}$ & 4.91 & 5.72 & 2.98 \\
\hline & $\mathrm{SO}_{4}{ }^{2-} \mathrm{mg} / \mathrm{L}$ & 5054.00 & 4205.00 & 4415.00 \\
\hline \multirow{3}{*}{$\begin{array}{l}\text { Amount of } \\
\text { precipitation }\end{array}$} & Recycled struvite & 48.60 & 49.80 & 44.70 \\
\hline & $\mathrm{CaO}$ pretreatment & 73.00 & 73.00 & 73.00 \\
\hline & Adjust $\mathrm{pH}$ & 35.00 & 41.40 & 35.00 \\
\hline \multicolumn{2}{|c|}{$\mathrm{pH}$ after reaction } & 8.6 & 7.6 & 7.8 \\
\hline
\end{tabular}

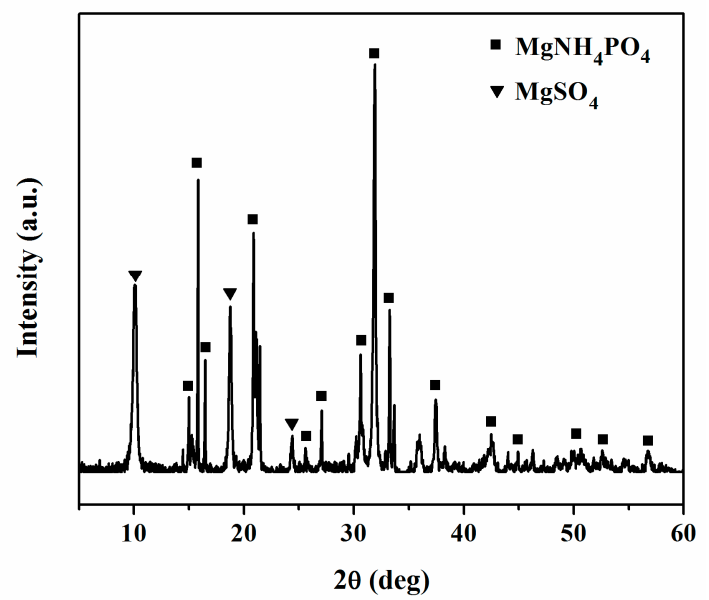

Figure 3. $\mathrm{XRD}$ patterns of struvite precipitation obtained by the reaction of $\mathrm{Mg}_{5}\left(\mathrm{CO}_{3}\right)_{4}(\mathrm{OH})_{2} \cdot 4 \mathrm{H}_{2} \mathrm{O}$ and $\mathrm{NH}_{4} \mathrm{Cl}$.

\subsection{SEM Analysis of Struvite Precipitation}

As shown in Figure 4, the precipitated powder obtained by the reaction of $\mathrm{Mg}_{5}\left(\mathrm{CO}_{3}\right)_{4}(\mathrm{OH})_{2} \cdot 4 \mathrm{H}_{2} \mathrm{O}$ and $\mathrm{NH}_{4} \mathrm{Cl}$ was magnified 1500 (A) and 8000 (B) times, respectively. As shown in Figure 4A, the struvite precipitation was observed as guano-like clusters. Combined with the experimental phenomena recorded during the experimental process, it was verified that the struvite deposits formed by the reaction are easy to settle in water, which is beneficial to the recycling and actual use. As shown in Figure 4B, the surface of the struvite sediment can be seen as a whole in a layered form, which indicates that the struvite precipitates in a layered manner, and is arranged neatly and regularly. However, it can also be seen that a small amount of irregular substances are mixed in, and the impurities do not have a specific form. According to the ionic data of the reaction process, it is likely that the residual $\mathrm{Mg}_{5}\left(\mathrm{CO}_{3}\right)_{4}(\mathrm{OH})_{2} \cdot 4 \mathrm{H}_{2} \mathrm{O}$ is undissolved solid, but the proportion is very small. 

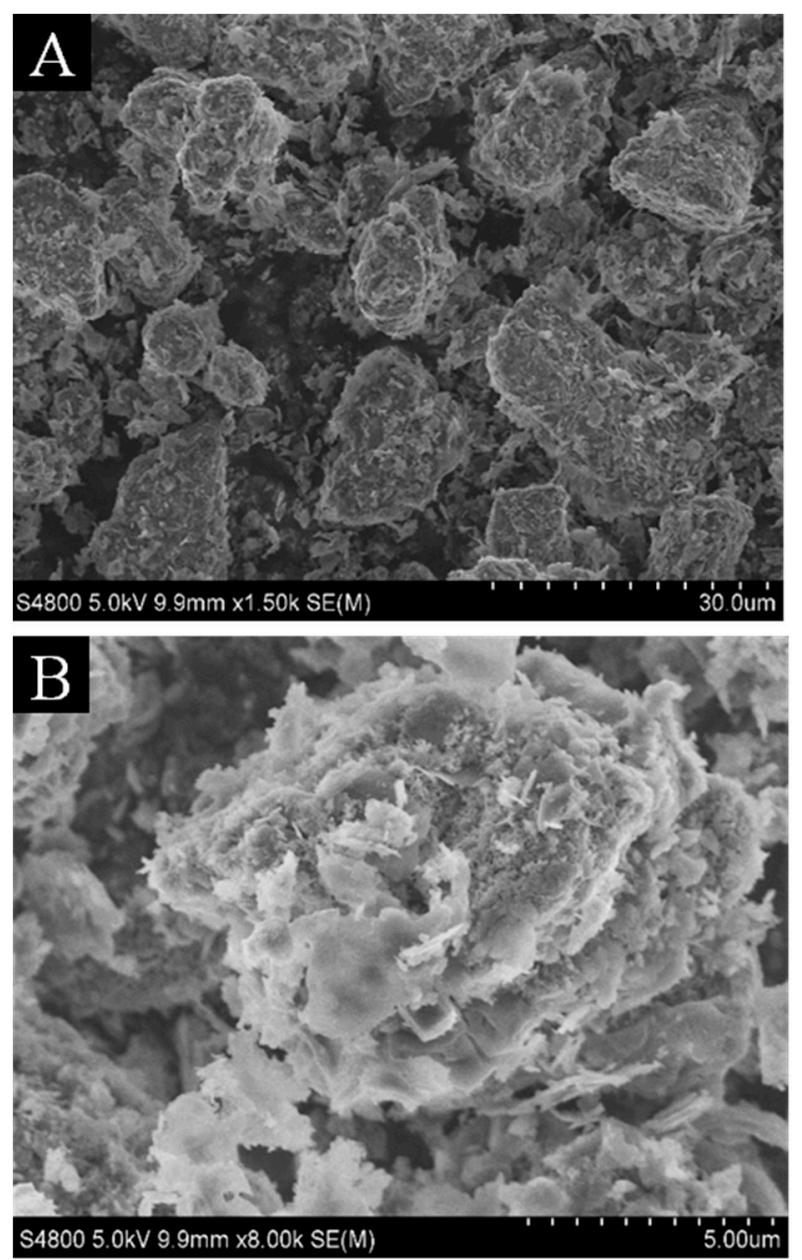

Figure 4. SEM diagram of the precipitated powder obtained by the reaction of $\mathrm{Mg}_{5}\left(\mathrm{CO}_{3}\right)_{4}(\mathrm{OH})_{2} \cdot 4 \mathrm{H}_{2} \mathrm{O}$ and $\mathrm{NH}_{4} \mathrm{Cl}$ magnified $1500(\mathrm{~A})$ and $8000($ B) times.

\subsection{Analysis of Nutrients in Struvite Precipitation}

The nutrient element analysis was performed on the precipitate generated under the conditions of initial $\mathrm{pH}$ of 4.0, Mg:N:P of 1.2:1.1:1, stirring reaction time of 30 minutes. The specific operation is: accurately weigh $0.50 \mathrm{~g}$ of the dried precipitate, dissolve it in dilute hydrochloric acid, and make it to a volume of $100 \mathrm{~mL}$; during measuring, the concentration is diluted according to different measurement ranges of $\mathrm{Mg}, \mathrm{N}$, and $\mathrm{P}$. The mass fraction of $\mathrm{Mg}, \mathrm{N}$, and $\mathrm{P}$ in the precipitate was calculated based on $\mathrm{MgO}, \mathrm{N}$, and $\mathrm{P}_{2} \mathrm{O}_{5}$ [24]. The results are shown in Table 5:

Table 5. Composition analysis of struvite precipitation.

\begin{tabular}{cccc}
\hline Ingredient Content & $\omega(\mathrm{MgO}) / \%$ & $\omega(\mathrm{N}) / \%$ & $\omega\left(\mathrm{P}_{\mathbf{2}} \mathrm{O}_{5}\right) / \%$ \\
\hline Theoretical value of struvite & 16.43 & 5.70 & 28.92 \\
\hline Actual value of precipitate & 17.08 & 4.00 & 25.22 \\
\hline
\end{tabular}

It can be obtained from Table 5 that the reference mass fractions of $\mathrm{Mg}, \mathrm{N}$, and $\mathrm{P}$ in the precipitate are close to the theoretical values of the corresponding mass fraction in struvite, which indicates that the main constituent of the precipitate is MAP. According to the classification standards of China's phosphate rock, phosphate rock has a mass fraction of $\mathrm{P}_{2} \mathrm{O}_{5}$ in the range of $20 \%$ to $30 \%$, which belongs to Grade II phosphate rock. Compared with natural phosphate rock, there is less toxic and harmful 
impurities in the struvite precipitation produced in this study, which is easy to purify and separate, and has more economic value [25].

\section{Conclusions}

In summary, the main aim of this work is studying the factors affecting the recovery of phosphorus in acidic ultrahigh-phosphorus wastewater by struvite crystallization, such as the proportion of reactant materials, initial $\mathrm{pH}$, and reaction time. A feasible TP treatment process is designed to make the TP concentration reach the discharge standard in the experiments. This work innovatively uses basic magnesium carbonate as the magnesium source in the struvite precipitation method, which has a higher solubility than magnesium hydroxide, and is more suitable for treating high-concentration acidic phosphorus-containing wastewater. With the conditions of using reagents of $\left[\mathrm{Mg}_{5}\left(\mathrm{CO}_{3}\right)_{4}(\mathrm{OH})_{2} \cdot 4 \mathrm{H}_{2} \mathrm{O}+\right.$ $\mathrm{NH}_{4} \mathrm{Cl}$, initial $\mathrm{pH}=4.0, \mathrm{Mg}: \mathrm{N}: \mathrm{P}$ molar ratio of 1.2:1.1:1, and reaction time of $30 \mathrm{~min}$, the remaining TP concentration was $2.98 \mathrm{mg} / \mathrm{L}$, and the TP removal rate reached $99.99 \%$. XRD pattern analysis confirmed that the main component of struvite sediment was ammonium magnesium phosphate. The nutritional element analysis of the generated struvite precipitated that the mass fraction in $\mathrm{P}_{2} \mathrm{O}_{5}$ reached $25.22 \%$, which is equivalent to high-grade phosphate rock, and it is determined that the recovered struvite has high economic value.

Author Contributions: Methodology, Q.L.; validation, S.W. and L.Z.; formal analysis, L.W.; data curation, Q.L.; writing - original draft preparation, Z.S., X.W., and S.W.; writing-review and editing, L.Z.; funding acquisition, L.Z. All authors have read and agreed to the published version of the manuscript.

Funding: This research was funded by Natural Science Foundation of China (Nos. 21806101, 51476094, 51590901), Natural Science Foundation of Shanghai (Nos. 16ZR1412600, 15ZR1416900), Gaoyuan Discipline of Shanghai-Environmental Science and Engineering (Resource Recycling Science and Engineering), Shanghai Eastern Professorship grant, Shu Guang project supported by Shanghai Municipal Education Commission and Shanghai Education Development Foundation (No. 15SG52).

Acknowledgments: The authors thank Zhongping Xu for his help in SEM characterization.

Conflicts of Interest: The authors declare no conflict of interest.

\section{References}

1. Tsuji, N.; Ito, Y.; Saito, Y.; Minamino, Y. Strength and ductility of ultrafine grained aluminum and iron produced by ARB and annealing. Scr. Mater. 2002, 47, 893-899. [CrossRef]

2. Lin, B.L.; Lu, J.T.; Kong, G. Synergistic corrosion protection for galvanized steel by phosphating and sodium silicate post-sealing. Surf. Coat. Technol. 2008, 202, 1831-1838. [CrossRef]

3. Akhtar, A.S.; Wong, K.C.; Mitchell, K.A.R. The effect of $\mathrm{pH}$ and role of $\mathrm{Ni}^{2+}$ in zinc phosphating of 2024-Al alloy. Part I: Macroscopic studies with XPS and SEM. Appl. Surf. Sci. 2006, 253, 493-501. [CrossRef]

4. Jin, Y.; Qu, R.; Zuo, Z.; Tang, H. Coating Process for Aluminium Alloy Structure of Bus. Paint Coat. Ind. 2016, $46,61-64$.

5. Li, Q.; Gu, P.; Ji, X.; Li, H.; Zhang, J.; Zheng, Z. Response of submerged macrophytes and periphyton biofilm to water flow in eutrophic environment: Plant structural, physicochemical and microbial properties. Ecotoxicol. Environ. Saf. 2020, 189, 109990. [CrossRef]

6. Othman, A.; Dumitrescu, E.; Andreescu, D.; Andreescu, S. Nanoporous Sorbents for the Removal and Recovery of Phosphorus from Eutrophic Waters: Sustainability Challenges and Solutions. ACS Sustain. Chem. Eng. 2018, 6, 12542-12561. [CrossRef]

7. Wang, B.; Zeng, W.; Fan, Z.; Wang, C.; Meng, Q.; Peng, Y. Effects of polyaluminium chloride addition on community structures of polyphosphate and glycogen accumulating organisms in biological phosphorus removal (BPR) systems. Bioresour. Technol. 2020, 297, 122431. [CrossRef]

8. Bertanza, G.; Menoni, L.; Capoferri, G.U.; Pedrazzani, R. Promoting biological phosphorus removal in a full scale pre-denitrification wastewater treatment plant. J. Environ. Manag. 2020, 254, 109803. [CrossRef] 
9. Qiang, J.; Zhou, Z.; Wang, K.; Qiu, Z.; Zhi, H.; Yuan, Y.; Zhang, Y.; Jiang, Y.; Zhao, X.; Wang, Z.; et al. Coupling ammonia nitrogen adsorption and regeneration unit with a high-load anoxic/aerobic process to achieve rapid and efficient pollutants removal for wastewater treatment. Water Res. 2020, 170, 115280. [CrossRef] [PubMed]

10. Gally, C.R.; Benvenuti, T.; da Trindade, C.D.M.; Rodrigues, M.A.S.; Zoppas-Ferreira, J.; Perez-Herranz, V.; Bernardes, A.M. Electrodialysis for the tertiary treatment of municipal wastewater: Efficiency of ion removal and ageing of ion exchange membranes. J. Environ. Chem. Eng. 2018, 6, 5855-5869. [CrossRef]

11. Koh, K.Y.; Zhang, S.; Chen, J.P. Hydrothermally synthesized lanthanum carbonate nanorod for adsorption of phosphorus: Material synthesis and optimization, and demonstration of excellent performance. Chem. Eng. J. 2020, 380, 122153. [CrossRef]

12. Hu, L.; Yu, J.; Luo, H.; Wang, H.; Xu, P.; Zhang, Y. Simultaneous recovery of ammonium, potassium and magnesium from produced water by struvite precipitation. Chem. Eng. J. 2020, 382, 123001. [CrossRef]

13. Pinatha, Y.; Polprasert, C.; Englande, A.J., Jr. Product and cost perspectives of phosphorus recovery from human urine using solid waste ash and sea salt addition-A case of Thailand. Sci. Total Environ. 2020, 713, 136514. [CrossRef] [PubMed]

14. Sena, M.; Morris, M.R.; Seib, M.; Hicks, A. An exploration of economic valuation of phosphorus in the environment and its implications in decision making for resource recovery. Water Res. 2019, 172, 115449. [CrossRef]

15. Duan, M.; O’Dwyer, E.; Stuckey, D.C.; Guo, M. Wastewater to Resource: Design of a Sustainable Phosphorus Recovery System. Chemistryopen 2019, 8, 1109-1120. [CrossRef] [PubMed]

16. Law, K.P.; Pagilla, K.R. Reclaimed phosphorus commodity reserve from water resource recovery facilities-A strategic regional concept towards phosphorus recovery. Resour. Conserv. Recycl. 2019, 150, 104429. [CrossRef]

17. Xie, M.; Nghiem, L.D.; Price, W.E.; Elimelech, M. Toward Resource Recovery from Wastewater: Extraction of Phosphorus from Digested Sludge Using a Hybrid Forward Osmosis-Membrane Distillation Process. Environ. Sci. Technol. Lett. 2014, 1, 191-195. [CrossRef]

18. Shimamura, K.; Ishikawa, H.; Mizuoka, A.; Hirasawa, I. Development of a process for the recovery of phosphorus resource from digested sludge by crystallization technology. Water Sci. Technol. 2008, 57, 451-456. [CrossRef]

19. Kekedy-Nagy, L.; Teymouri, A.; Herring, A.M.; Greenlee, L.F. Electrochemical removal and recovery of phosphorus as struvite in an acidic environment using pure magnesium vs. the AZ31 magnesium alloy as the anode. Chem. Eng. J. 2020, 380, 122480. [CrossRef]

20. Babic-Ivancic, V.; Kontrec, J.; Brecevic, L.; Kralj, D. Kinetics of struvite to newberyite transformation in the precipitation system $\mathrm{MgCl}_{2}-\mathrm{NH}_{4} \mathrm{H}_{2} \mathrm{PO}_{4}-\mathrm{NaOH}-\mathrm{H}_{2} \mathrm{O}$. Water Res. 2006, 40, 3447-3455. [CrossRef]

21. Fischer, F.; Bastian, C.; Happe, M.; Mabillard, E.; Schmidt, N. Microbial fuel cell enables phosphate recovery from digested sewage sludge as struvite. Bioresour. Technol. 2011, 102, 5824-5830. [CrossRef] [PubMed]

22. Tanaka, H.; Hagiwara, A.; Kurata, Y.; Ogiso, T.; Futakuchi, M.; Ito, N. Thirteen-week oral toxicity study of magnesium chloride in $\mathrm{B}_{6} \mathrm{C}_{3} \mathrm{~F}_{1}$ mice. Toxicol. Lett. 1994, 73, 25-32. [CrossRef]

23. Agudosi, E.S.; Salleh, M.A.M.; Abdullah, E.C.; Mubarak, N.M.; Khalid, M.; Azni, A.A. Characterization of crystallized struvite on wastewater treatment equipment: Prospects for crystal fertilizer production. Desalin. Water Treat. 2018, 113, 205-212. [CrossRef]

24. Wen, G.; Huang, L.; Zhang, X.; Hu, Z. Uptake of nutrients and heavy metals in struvite recovered from a mixed wastewater of human urine and municipal sewage by two vegetables in calcareous soil. Environ. Technol. Innov. 2019, 15, 100384. [CrossRef]

25. Fan, X.; Rui, Y.; Han, X.; Yang, J.; Wang, Y.; Zhang, Q. Spray-coated monodispersed $\mathrm{SnO}_{2}$ microsphere films as scaffold layers for efficient mesoscopic perovskite solar cells. J. Power Sources 2020, 448, 227405. [CrossRef]

(C) 2020 by the authors. Licensee MDPI, Basel, Switzerland. This article is an open access article distributed under the terms and conditions of the Creative Commons Attribution (CC BY) license (http://creativecommons.org/licenses/by/4.0/). 